\title{
Wing morphometrics of Aedes (Ochlerotatus) albifasciatus (Macquart, 1838) (Diptera: Culicidae) from different climatic regions of Argentina
}

Maximiliano J. Garzón ${ }^{1,2^{*}}$ and Nicolás Schweigmann ${ }^{1,2}$

\begin{abstract}
Background: Gene flow restrictions between populations of Aedes albifasciatus, the vector of Western equine encephalitis and Dirophilaria immitis, have been described in the central region of Argentina. Genetic and eco-physiological variations usually result in local forms reflecting the climatic regions. Mosquito wings and their different parts have ecological functions in flight and communication. Therefore, wing shape could be considered an aspect of sexual dimorphism, and its eco-physiological responses can be expressed as morphological changes induced by the environment.

Methods: To compare the geographical and sexual variations with respect to wing shape and size in two Ae. albifasciatus populations from contrasting climates of Argentina (temperate: Buenos Aires, and the arid steppe of Patagonia: Sarmiento), the wings of adults reared in thermal trays at different constant temperatures $\left(10-29^{\circ} \mathrm{C}\right)$ were analyzed.

Results: The wing size of Ae. albifasciatus showed inverse linear relationships with the rearing thermal condition and higher slope for Buenos Aires. In the cool range $\left(10-17^{\circ} \mathrm{C}\right)$, geographical size variations responded to the converse Bergmann's rule, where Buenos Aires individuals were larger than those from Sarmiento. Sexual shape dimorphism occurred in both populations while geographical variation in shape was observed in both sexes.

Conclusions: Buenos Aires individuals showed greater response sensitivity with respect to the size-temperature relation than those from Sarmiento. The converse Bergmann's rule in size variation could be due to a higher development rate in Sarmiento to produce more cohorts in the limited favorable season. The shape could be more relevant with respect to the size in the study of population structures due to the size being more liable to vary due to changes in the environment. The geographical variations with respect to morphology could be favored by the isolation between populations and adaptations to the environmental conditions. Our results demonstrate that the shape and size of wing provide useful phenotypic information for studies related to sexual and environmental adaptations.
\end{abstract}

Keywords: Aedes albifasciatus, Geometric morphometrics, Wings, Size, Shape, Dimorphism, Thermal ranges

\footnotetext{
*Correspondence: maxigarzon@yahoo.com.ar

'Departamento de Ecología, Genética y Evolución, Grupo de Estudio de Mosquitos, Universidad de Buenos Aires, Facultad de Ciencias Exactas y Naturales, Buenos Aires, Argentina

${ }^{2}$ Universidad de Buenos Aires, Consejo Nacional de Investigaciones

Científicas y Técnicas, Instituto de Ecología, Genética y Evolución de Buenos

Aires (IEGEBA), Facultad de Ciencias Exactas y Naturales, Buenos Aires,

Argentina
}

(C) The Author(s). 2018 Open Access This article is distributed under the terms of the Creative Commons Attribution 4.0 International License (http://creativecommons.org/licenses/by/4.0/), which permits unrestricted use, distribution, and reproduction in any medium, provided you give appropriate credit to the original author(s) and the source, provide a link to the Creative Commons license, and indicate if changes were made. The Creative Commons Public Domain Dedication waiver (http://creativecommons.org/publicdomain/zero/1.0/) applies to the data made available in this article, unless otherwise stated. 


\section{Background}

Aedes (Ochlerotatus) albifasciatus is a sylvatic mosquito from the Southern Cone of South America, with explosive abundances due to flood waters related to rainfall, overflow of rivers [1], and/or increase in the groundwater layers. Aedes albifasciatus was the first mosquito species incriminated as a vector of the western equine encephalitis virus [2]. This species has also been related to Saint Louis encephalitis virus [3] and Bunyamwera virus [4], and is a potential vector of Dirofilaria immitis [5]. This species is distributed from $17^{\circ} \mathrm{S}$ [6] to $54^{\circ} \mathrm{S}$ in Tierra de Fuego, Argentina [7]. Its geographical range includes different regions $[8,9]$ with different types of landscapes, environments and climates. Aedes albifasciatus has even been found to be adapted to extreme places such as elevated sites [10] and brackish water microenvironments [11], as well as tolerating strong wind bursts [12].

Previous studies have demonstrated that differences in the genetic divergence in Ae. albifasciatus are related to gene flow restrictions between breeding areas of different geographical populations $[13,14]$. Otherwise, some temperature-dependent life-cycle parameters, such as development time and survival, present geographical variations [15]. These genetic and eco-physiological variations may result in local morphological forms (relative to size and shape) in response to contrasting climatic regions $[16,17]$.

Insect wings have ecologically important functions in flight and communication, and in fact various insects show intraspecific polymorphism in wing shape, making wings a target of natural selection [18]. The morphological characteristics of the different parts of the wing are closely related to the flight aerodynamics $[19,20]$.

In mosquitoes, only females are hematophagous and pathogen-competent and use their wings to ensure an accurate approach to other animals to suck their blood, while males can copulate with several mates and use wing beats to attract the opposite sex during courtship [21]. Therefore in mosquitoes, the wing shape and size could be considered an aspect of sexual dimorphism by their sex-specific function. Additionally, their ecophysiological responses include phenotypic plasticity, which can be expressed as changes in the morphology of the individuals of a population, such as those observed in the wings of mosquitoes. Plasticity can be induced by any environmental factor, and the resulting changes can vary from weak forms to well-adapted phenotypes [22]. The phenotypic variations related to the size and shape can be analyzed by morphometric techniques [23]. Both molecular and morphometric techniques [24, 25] have allowed the observation of intraspecific variability in insects, particularly in mosquitoes [26-28]. Geometric morphometrics has been used as a tool to analyze population structure [29], evolutionary units [30], genetic divergences in local populations [31], altitudinal variations [32] and different selective effects such as rearing conditions [33-35].

The objective of this study was to compare geographical and sexual morphological variations (wing shape and size) in two Argentinian populations of Ae. albifasciatus from contrasting climates and their response to different rearing temperature conditions. For this purpose, geometric morphometrics was used as a first approach to the comparative study at the population level.

\section{Methods}

Study sites

Aedes albifasciatus mosquitoes were collected in two sampling sites: Buenos Aires $\left(34^{\circ} 36^{\prime} \mathrm{S}, 58^{\circ} 26^{\prime} \mathrm{W}\right.$, located in the Pampas plain) and Sarmiento Valley $\left(45^{\circ} 35^{\prime} \mathrm{S}, 69^{\circ} 05^{\prime} \mathrm{W}\right.$, located in the Patagonian steppe) (Fig. 1). The climate in Buenos Aires is humid temperate [36], with warm summers (average $25^{\circ} \mathrm{C}$ ) and cool winters (average $12{ }^{\circ} \mathrm{C}$ ). Winter is the wettest season of the year, with averages of $74-79 \%$ Relative Humidity $(\mathrm{RH})$. In summer, the $\mathrm{RH}$ reaches values of $63-68 \%$. The climate in Sarmiento valley is arid [36] with warm summers (average $18{ }^{\circ} \mathrm{C}$ ), with daily desert thermal amplitude, and very cold winters (average $4{ }^{\circ} \mathrm{C}$ ). In the cold season, the average monthly $\mathrm{RH}$ is approximately $75-80 \%$ (rainfall period), whereas in summer, the $\mathrm{RH}$ is $40 \%$ and precipitation does not reach the average of $15 \mathrm{~mm}$. Moreover, the summer season is characterized by being very windy, with strong gusts (mean speeds ranging between 8 and $30 \mathrm{~km} / \mathrm{h}$ ) between calm periods [37, 38].

\section{Biological material}

In the summer period (2010-2011), females of Ae. albifasciatus were caught in the field, taken to the laboratory (located near the natural breeding sites), and placed in three cages. For this species has not been possible to maintain colonies under laboratory conditions, probably

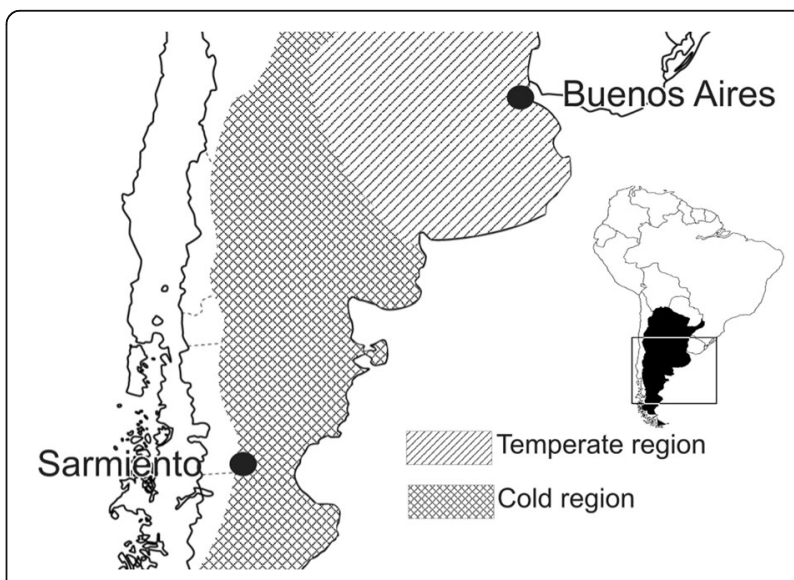

Fig. 1 Study sites and climatic regions of Argentina (by Peel et al., 2007) where females of Aedes (Ochlerotatus) albifasciatus were captured 
due to its eurygamic characteristics, as in other species of the subgenus Ochlerotatus [39]. Consequently, to keep 150 individuals per cages approximately, dead individuals were replaced daily (about 30-50 adults). As a source of blood for egg laying, females were blood-fed on mammals (rabbits or nursing mice), where laboratory animal ethics protocols were followed according to the University of Buenos Aires regulations (R 4081/2004).

A Petri dish with absorbent paper on damp cotton was offered as an oviposition substrate in each of the cages with females. For the experiments, different portions of these substrates were randomly selected for the purpose of using eggs from different individuals. Eggs were induced to hatch by immersing them in a yeast solution. Then, approximately 30 larvae were placed randomly in individual containers (cylindrical containers measuring $3 \mathrm{~cm}$ in diameter and $5 \mathrm{~cm}$ high with $10 \mathrm{ml}$ of dechlorinated tap water) in thermal trays at constant temperatures in a range of $10-29{ }^{\circ} \mathrm{C}\left(3^{\circ} \mathrm{C}\right.$ step) until they reached their adult form [15]. As the temperatures of the trays could be affected by ambient conditions, we placed temperature data loggers $\left(\mathrm{Hobo}^{\circ}\right.$, Onset Computer Corporation, Bourne, MA, USA) in the trays, and took the mean recorded temperature instead of the system thermostat sensor reading. The photoperiod during rearing was 14:10 h (light: dark) and the individuals were fed daily with an aliquot of $\operatorname{dog}$ chow (Purina ${ }^{\circ}$, San Luis, MO, USA), as follows: instar I: $0.2 \mathrm{mg} /$ day, instar II: $0.3 \mathrm{mg} /$ day, instar III: $0.4 \mathrm{mg} /$ day and instar IV: $0.6 \mathrm{mg} /$ day [40]. After completion of development, adults which emerged successfully were sacrificed at freezing temperatures $\left(-12{ }^{\circ} \mathrm{C}\right)$. A total of 135 specimens were able to be photographed and analyzed: 24 males and 36 females from Buenos Aires and 32 males and 43 females from Sarmiento valley.

To evaluate the geographical variation and sexual dimorphism as a function of the thermal range, the temperatures tested were divided into two sub-ranges: cool $\left(10-17{ }^{\circ} \mathrm{C}\right)$ and warm $\left(19-29^{\circ} \mathrm{C}\right)$, based on the fact that the populations studied respond differently to the time of development as a function of warm or cool temperatures [15], which directly affects their size.

\section{Wing processing, centroid size and shape}

The left wings of each individual were removed from the thorax by using a fine clamp, placed between glass slides and photographed with a camera (Leica ${ }^{\circ}$ DFC 295; Leica Camera AG, Solms, Germany) coupled with a stereoscopic microscope (Leica ${ }^{\circ}$ S8 APO; Leica Camera AG, Solms, Germany). Once the digital image was obtained, 17 points of the wing (natural intersections given by the venation) or landmarks (LMs) (Fig. 2) were selected from references, and the software tps-DIG 2.16 [41] was used to generate Cartesian coordinates in two dimensions for each individual. The LM configurations obtained were transferred, rotated and scaled according to the generalized Procrustes method [42], using Morpho ${ }^{\circledR}$ software 1.05 [43]. Thus, the new Procrustes coordinates were generated to be used as shape variables. To compare the size of the wing between the different groups (sex or population), the centroid size (CS), derived from Cartesian coordinate data, was used as an isometric size estimator. The CS is defined as the square root of the sum of the square of the distances between the center of the configuration of the LM (or centroid) and each LM [42]. Since the CS is based on Cartesian coordinates (XY), the result of the calculation mentioned above is a one-dimensional scale. For the analysis, the morpho-geometric sizes (CS) were logarithmized (log CS).

The software used to obtain, process and analyze the data (tps-DIG 2.16, Morpho广 ${ }^{\circ}$ ) is freeware (http://life.bio. sunysb.edu/morph/).

\section{Data analysis}

To study the relationship between size and temperature, the logarithm of the CS against the rearing temperature was linearly fitted for each sex and population separately. Then, the slopes were compared by a test of parallelism in both populations and sexes [44]. The size differences between sex and population were statistically evaluated using the $\log$ CS in a parametric two-way ANOVA [45]. Due to the low survival of the individuals in both populations at warm range, only data for the cool range were subjected to statistical tests.

The allometric influence of wing size on wing shape was assessed by multivariate regression of the Procrustes coordinates (shape) against CS, using a permutation test with 10,000 randomizations [46, 47].

Two-way multivariate analysis of variance (MANOVA) was used to compare and discriminate wing shapes between the populations and sexes. Previously, the variables of the shape (without the allometric effect) were summarized by means of a principal components analysis (PCA) where the PCs generated were taken as new variables of the shape. Canonical variate analysis (CVA) combined with discriminant analysis (DA) was performed [47] to evaluate the differences between sex and population.

To compare Procrustes distances between groups, a permutation test with 10,000 iteration rounds was performed. The square root of the sum of the squared distances between the corresponding LMs of two aligned configurations is an approximation of the Procrustes distance [48], which is a measure of shape variation. In all cases, a significance level $\alpha=0.05$ was used. To visualize the morphological changes in the wings, deformation vectors were used with respect to a consensus configuration and a thin-plate spline or wireframe scheme $[43,47]$, using the software Morpho ${ }^{\circ}$ 1.05. The comparison between thermal ranges respect to 


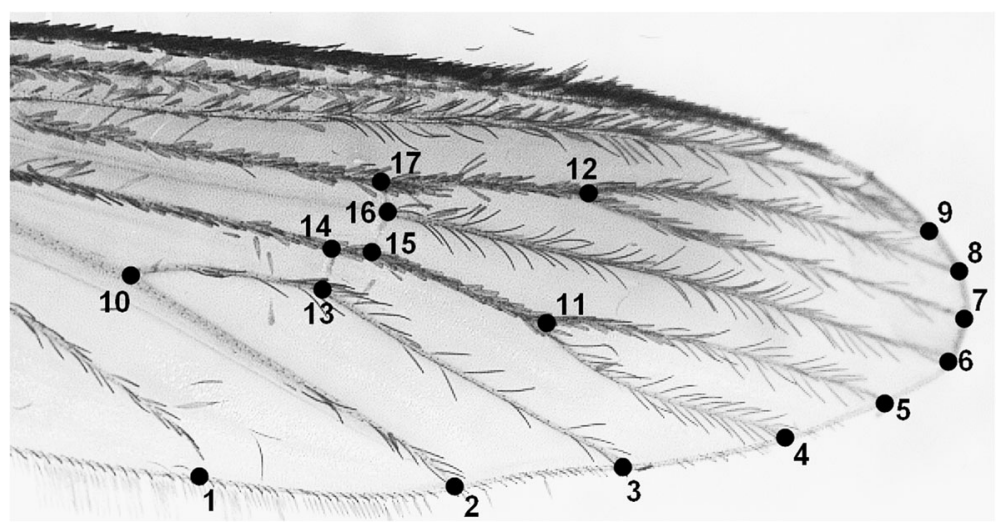

Fig. 2 Location of the 17 landmarks (LMs) on the wings of Aedes (Ochlerotatus) albifasciatus

the shape was not analyzed due to a low sample size in both populations at warm range.

The variability of population and sex shapes was estimated with CS of scatter plots within the morpho-space formed by the first PCs (for instance, PC1:X and PC2: Y) , similar to that described in Louise et al. [49]. For the comparison between groups, we generated CS values and performed two-way ANOVA.

\section{Results}

\section{Centroid size}

For both populations (Buenos Aires, Sarmiento) and for both sexes (males and females), the wing size (log CS) showed an inverse relationship with the rearing temperature (Fig. 3). The simple linear regressions were significant for the slope in all the cases, and the linear fit $\left(r^{2}\right)$ was better for the individuals from Buenos Aires (males Buenos Aires: $r^{2}=0.7110, P=0.0000004, \mathrm{y}=$ $7.5032-0.0328 \% x$; females Buenos Aires: $r^{2}=0.7076$, $P=0.00003, \mathrm{y}=7.6401-0.0331^{*} \mathrm{x}$; males Sarmiento: $r^{2}=0.5097, P=0.000004, y=7.0732-0.0176^{*} \mathrm{x}$; and females Sarmiento: $r^{2}=0.4168, P=0.000003, y=7.1921$ $\left.0.0185^{*} \mathrm{x}\right)$. Tests of parallelism indicated no differences between sexes for each population (Buenos Aires: $n=60$, $F_{(1,56)}=0.00054, P=0.9816$; Sarmiento: $n=75, F_{(1,71)}=$ $0.04, P=0.8433)$, but there were differences between

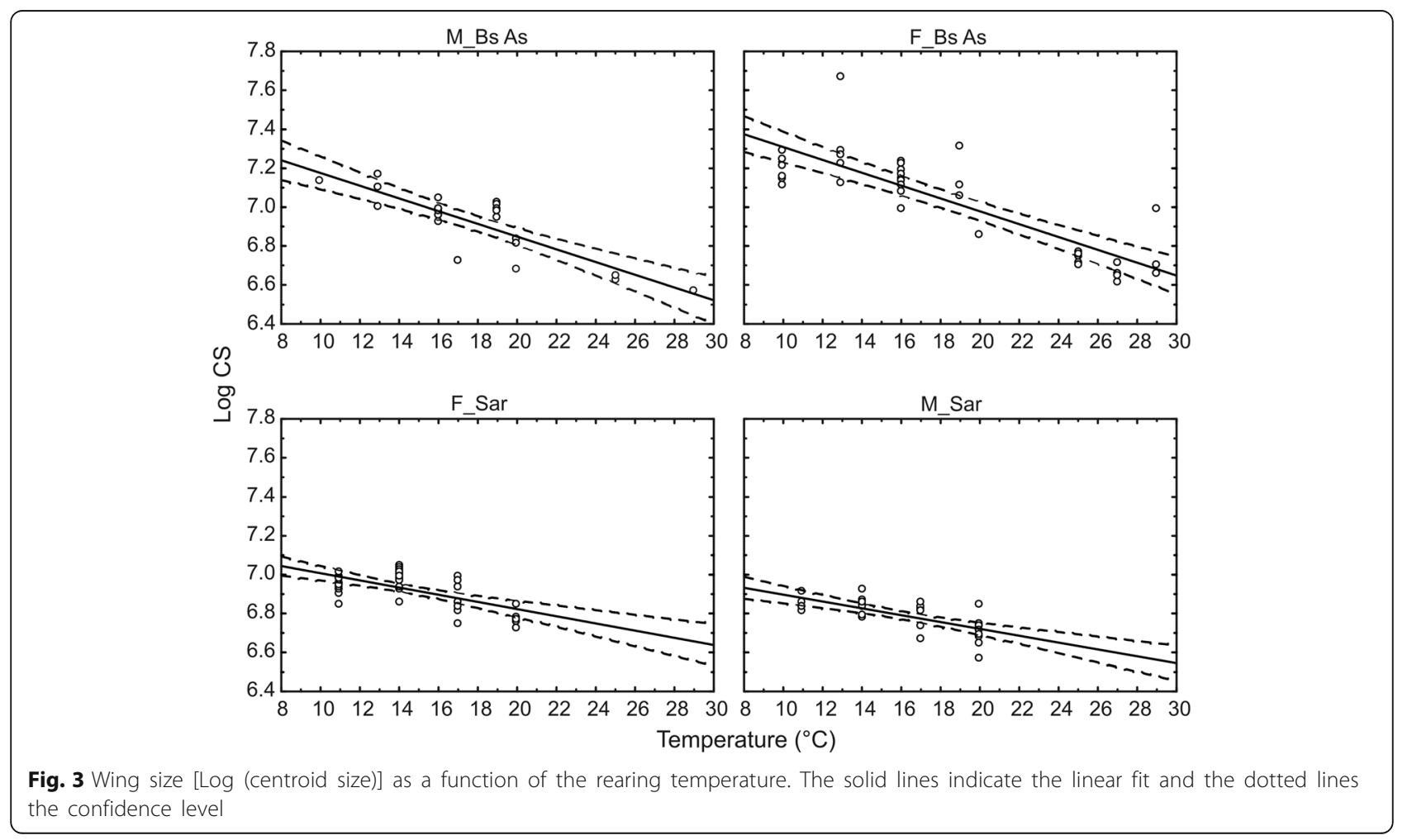


populations within each sex (males: $n=56, F_{(1,51)}=8.16$, $P=0.0062$; females: $\left.n=79, F_{(1,75)}=5.86, P=0.0179\right)$.

The mean sizes (log CS) in the cool thermal range were: males Buenos Aires $(n=18)=7$, males Sarmiento $(n=21)=6.83$, females Buenos Aires $(n=23)=7.2$ and females Sarmiento $(n=37)=6.95$. The ANOVA showed no interaction between sex and population $\left(F_{(1,93)}=3.35\right.$, $P=0.0704)$. Regarding the main effects, the results showed sexual size dimorphism $\left(F_{(1,93)}=91.36, P<\right.$ $0.0001)$, with females being larger than males regardless of the population and with the individuals from Buenos Aires being larger than those from Sarmiento $\left(F_{(1,93)}=\right.$ 159.58, $P<0.0001$ ) regardless of the sex (Fig. 4).

The size means in the warm thermal range were: males Buenos Aires $(n=6)=6.69$; males Sarmiento $(n=$ 11) $=6.71$; females Buenos Aires $(n=13)=6.73$ and females Sarmiento $(n=6)=6.77$ (Fig. 4).

\section{Shape}

The allometric test was significant $(P=0.001)$ and the proportion of total shape variation explained by the fact that the regression (analog to $r^{2}$ ) was lower than 9\%. Although the allometric level was low, it was removed for the shape analyses.

After removing the allometric effect, the PCA was carried out on shape variables (regression residuals), where the first six components (explaining $81 \%$ of the variance) were conserved according to the Kaiser criteria (eigenvalues greater than 1) as new shape variables. MANOVA showed that the shape was significantly different between populations and between sexes (Pillai, Lawley-Hotelling and Roy tests with: $F_{(6,124)}=186.12$ and $P<0.0001$ for sex level; $F_{(6,124)}=13.83$ and $P<0.0001$ for population level; and $F_{(6,124)}=1.57$ and $P=0.1401$ for the sexpopulation interaction).

The CVA revealed differences in shape between sexes and populations (Fig. 5). Canonical variable 1 (CV1), which explained $84 \%$ of the total variance, showed a clear sex separation, whereas CV2, which explained $12 \%$ of the total variance, indicated a distinction between populations. The Procrustes distances of shapes between sexes (Buenos Aires $_{\text {males-females: }}$ 0.89; Sarmiento males-fe- $_{\text {- }}$ males: 0.88 ) were higher than between populations

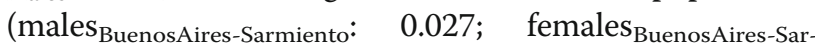
miento: 0.028). The permutation test $(10,000$ iteration rounds) for Procrustes distances was significant $(P<0.005)$.

These differences between sexes are shown in Fig. 6, where rectangles indicate the relevant area of the wing. The differences were at the wing width level and, as expected, these were more contrasting between the sexes, where the narrower form was that for males. Regarding the differences between populations, although less conspicuous, the results show that the wings of Sarmiento individuals are slightly thinner with respect to Buenos Aires (Fig. 6).

The thin-plate spline showed that the LMs 1, 11 and 12 were the most important in the shape changes, associated with CV1, in the sex separation. In CV2, LMs 1, 2, 10 and 9 explained the remaining variance between the populations.

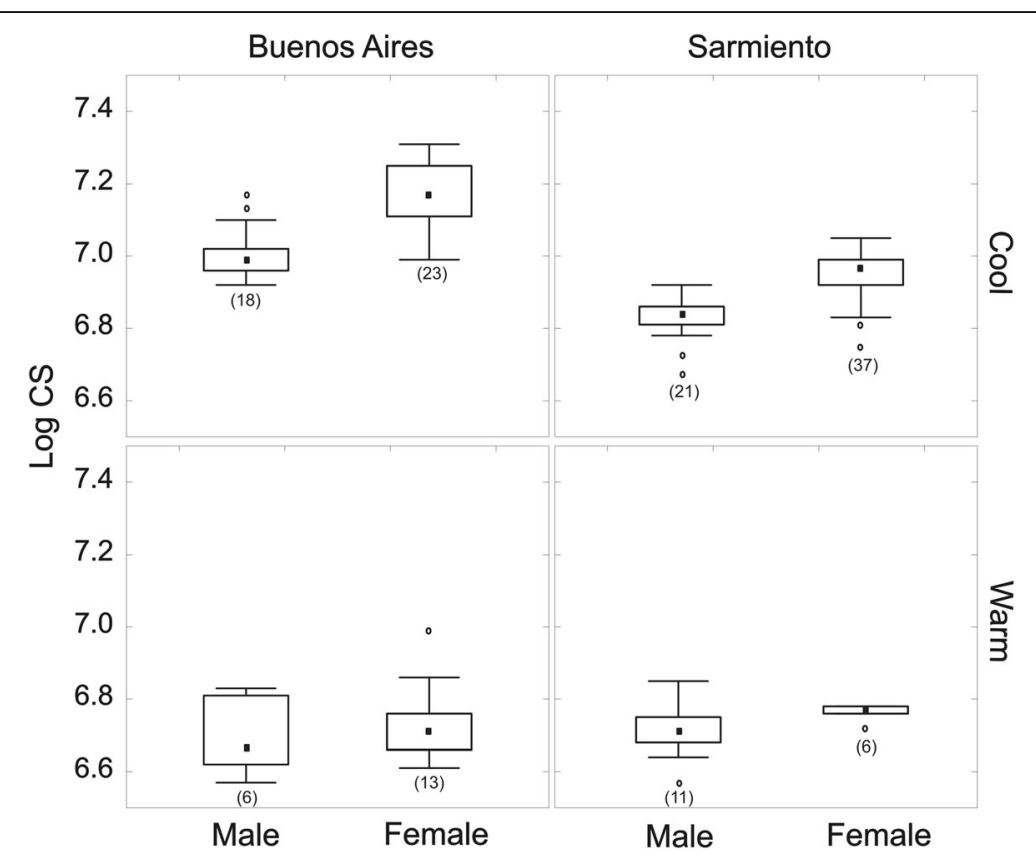

Fig. 4 Centroid size (Log CS) distribution in the wings of Aedes (Ochlerotatus) albifasciatus populations from Buenos Aires and Sarmiento, for cool $\left(10-17^{\circ} \mathrm{C}\right)$ and warm $\left(19-29^{\circ} \mathrm{C}\right)$ thermal ranges. Numbers in parentheses indicate sample sizes $(n)$ 


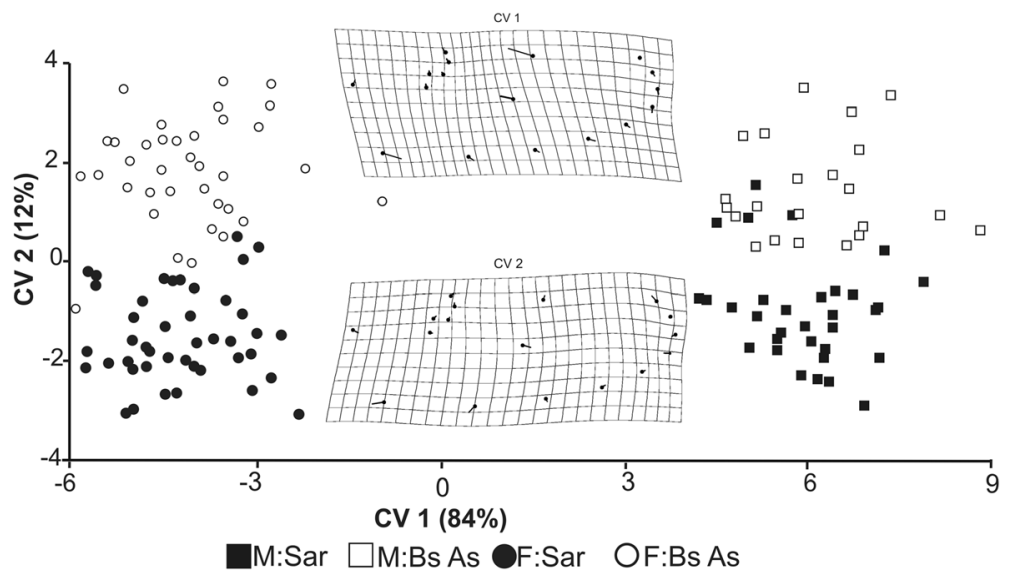

Fig. 5 Canonical variables (CV1 and CV2) for wing shape configuration of Aedes (Ochlerotatus) albifasciatus: Males from Sarmiento (filled squares) and Buenos Aires (empty squares); Females from Sarmiento (filled circles) and Buenos Aires (empty circles). Changes in wing shape through the canonical variables (CV1: 84\% and CV2: 12\%) are illustrated with a thin-plate spline. Thick points indicate the consensus configuration and the vectors (segments) indicate the relative relevance landmarks in the discrimination

The DA of pairs allowed separating the populations of the same sex and the sexes within the same population. Because the sample size was relatively small in relation to the variables to be analyzed (17 LMs), the cross-validation classification was carried out (Table 1). In females, $25 \%$ of the specimens from Buenos Aires were misclassified as Sarmiento and $21 \%$ of those from Sarmiento were classified as Buenos Aires, whereas in males, $33 \%$ of the specimens from Buenos Aires were misclassified as Sarmiento and 28\% of those from Sarmiento were misclassified as Buenos Aires. No classification errors were detected between sexes (Table 1).

\section{Shape variability}

Five CS values were obtained for shape variability in each group. ANOVA showed that the shape variability of females (mean $=558.7)$ was significantly higher than that of males $($ mean $=393.6)\left(\right.$ sex main effect: $F_{(1,16)}=$ $40.71, P=0.0001$ ). No significant differences were observed between populations (population main effect: $\left.F_{(1,16)}=0.65, P=0.4315\right)$. The sex-population interaction was not significant $\left(F_{(1,16)}=1.82, P=0.1959\right)$.

\section{Discussion}

The geometric morphometrics of the wings for Ae. albifasciatus allowed us to comparatively study the sexual

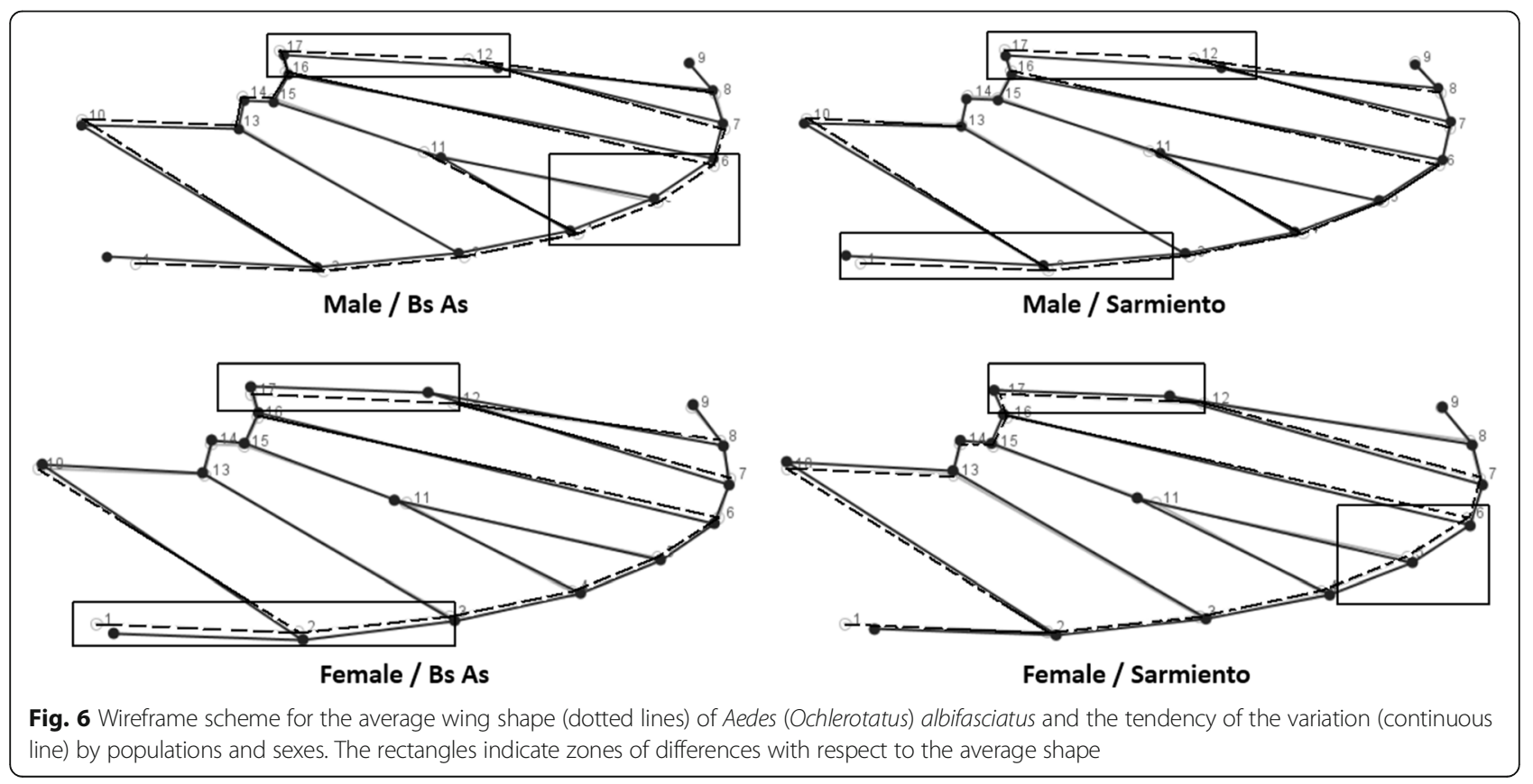


Table 1 Cross-validation classification for Ae. albifasciatus from discriminant analysis of pairs (by populations and sexes)

\begin{tabular}{|c|c|c|c|c|}
\hline \multicolumn{5}{|c|}{ Proportion of misclassification } \\
\hline Groups compared & BsAs F & Sar F & BsAs M & Sar M \\
\hline \multicolumn{5}{|c|}{ Geographical variation } \\
\hline BsAs F - Sar F & $9 / 36$ & $9 / 43$ & & \\
\hline BsAs M - Sar M & & & $8 / 24$ & $9 / 32$ \\
\hline \multicolumn{5}{|l|}{ Sexual dimorphism } \\
\hline BsAs F- BsAs M & $0 / 36$ & & $0 / 24$ & \\
\hline Sar F - Sar M & & $0 / 43$ & & $0 / 32$ \\
\hline
\end{tabular}

Abbreviations: BsAs $F$ Buenos Aires females, BsAs $M$ Buenos Aires males, Sar $F$ Sarmiento females, Sar $M$ Sarmiento males

dimorphism and the variability of individuals from different regions. It is known that geographical differences may exist in the vector competence in mosquitoes, observed in differences in infection and transmission rates $[50,51]$.

A negative linear relation between the body size magnitude and the breeding temperature has been observed for wing lengths [52, 53], femur lengths [53], cephalic capsule [54] and dry weight [52]. Although there is a good fit between wing length and centroid size [55], the centroid size is more representative of the magnitude of the individual because its multidimensionality summarizes the global size variation [23]. The slopes indicate that the response of size change (centroid) to the temperatures for both sexes are the same. This would indicate the same metabolic response, where the physical assimilation of nutrients is lower with the increase in temperature, since the development is more accelerated $[15,56]$.

\section{Sexual size and shape dimorphism}

In the cool thermal range, there was sexual dimorphism of sizes for both populations. This difference is the result of a lower development time for males (protandry) resulting in a smaller body size [57]. In most insect species, females are expected to reach a larger size than males due to the important role of population fitness [58]. In the warm thermal range a tendency of sexual dimorphism with larger females is observed (small size of the sample did not allow applying a statistical test).

The results suggest a sexual shape dimorphism for $A e$. albifasciatus populations, with more marked differences than between the geographical populations. This sexual dimorphism was evident, resulting in accurate classifications (100\% success) (Table).

The wings of the females were wider in the anteriorposterior sense, while the males had narrower wings. The wireframe (Fig. 6) confirmed this difference. This feature could optimize flight according to its sex-specific functionality, since Ae. albifasciatus is eurygamic, namely, it mates in swarms in open spaces [59] and, as in other species, each sex would recognize its mating pair through the sound of its wings during flight [60]. On the other hand, females must fly accurately to find the host [61] and then find a suitable site for oviposition. The sexual shape dimorphism would represent another evolutionary example in homologous structures [62], where the shape is canalized by sexual selection or other evolutionary mechanisms [21].

Regarding shape variability, the wings of Ae. albifasciatus females showed greater variability of shapes than those of males, indicating a greater sensitivity to the different rearing temperature conditions [58] and suggesting a more conspicuous phenotypic plasticity. Something similar has been recorded for females of $A e$. albopictus, in which the rate of change was higher than that recorded for males [61].

\section{Geographical variation in size and shape}

The centroids size-temperature relation in Ae. albifasciatus individuals from Sarmiento showed a lower slope than those from Buenos Aires, suggesting a more robust or less sensitive response to the gradual change in the rearing temperature. This characteristic could be a local adaptation to the local climatic region (Patagonian) where the larval state must resist the daily thermal amplitude [36]. Local adaptations have also been suggested for other life-cycle parameters such as development time and survival [15].

Insects usually respond to environmental conditions following the James rule [63] (which is similar to Bergmann's rule [64]) or the converse Bergmann's rule [65]. The James rule explains the increase in body size with latitude or decreasing temperature [66]. In contrast, in the converse Bergmann's rule, the size decreases with latitude, as a consequence of a shorter favorable season and an increase in developmental metabolism. The latter rule is common among univoltine insects [67] and has a genetic basis since this type of response has been observed both in field and laboratory studies [68]. Under cool rearing thermal ranges in the laboratory, Ae. albifasciatus individuals from Buenos Aires were larger than those from Sarmiento (Fig. 4). The lower accumulation of biomass by the individuals would be due to a higher rate of development [15] as a physiological response to the local environmental conditions [69]. Therefore, the individuals from Patagonia could follow the converse Bergmann's rule, although Ae albifasciatus is a multivoltine species, where an increase in metabolism could produce more cohorts in a limited favorable season (summer) [12], resulting in individuals of smaller size than those from Buenos Aires.

In Buenos Aires and other temperate populations, individuals rear and can be active throughout the year [70, 71], suggesting a lower selective pressure (accelerated 
metabolism) with respect to the development time observed in the Sarmiento population.

The geographical differences of wing shape in Ae. albifasciatus could indicate a geographical polymorphism or population structure, favored by the isolation between populations, since Sarmiento valley is surrounded by a desert steppe matrix. On the other hand, the shape differences between populations should reflect the arid or temperate environmental conditions [24].

The difference of the wing shape between studied populations could indicate an adaptation in relation to flight dynamics $[19,20]$. In a windy environment such as the Patagonian arid steppe during the summer time [38], the favorable Ae. albifasiatus season [12], thinner wings could be more favorable to avoid being displaced.

It is known that the individual or population variations of the wing shape and size are selected depending on the characteristics of the environment [72]. The architecture of morphological characters responds to the engagement between the demands of the environment and those of the genome [25]. Therefore, complementary molecular studies could explain the proportion explained by the genotype and the proportion explained by the environment.

In many circumstances, alternative phenotypes in response to environmental changes could be an adaptive strategy to maximize fitness in variable environments [73, 74].

\section{Conclusions}

The results of the present study evidenced sexual shape dimorphism in Ae. albifasciatus for the two populations and sexual size dimorphism in cool temperature rearing conditions (and probably a warm range). Shape geographical variation in individuals of Ae. albifasciatus, regardless of the sex, could indicate a population polymorphism between geographical regions. Size geographical variation was observed only in cool rearing temperatures, according to the converse Bergmann's rule. Furthermore, an inverse relationship between size and temperature was demonstrated for the two populations studied, although individuals from Buenos Aires showed greater response sensitivity than those from Sarmiento. Our results demonstrate that the shape and size of wing provide useful phenotypic information for studies related to sexual and environmental adaptations.

\section{Abbreviations}

RH: Relative humidity; LMs: Landmarks; LM: Landmark; CS: Centroid size; ANOVA: Analysis of variance; MANOVA: Multivariate analysis of variance; PCA: Principal components analysis; CVA: Canonical variate analysis; DA: Discriminant analysis; PC: Principal component; CV: Canonical variate

\section{Availability of data and materials}

The datasets used and/or analyzed during the current study are available from the corresponding author upon reasonable request.
Authors' contributions

All authors read and approved the final manuscript.

Ethics approval and consent to participate

Not applicable.

\section{Competing interests}

The authors declare that they have no competing interests.

\section{Publisher's Note}

Springer Nature remains neutral with regard to jurisdictional claims in published maps and institutional affiliations.

Received: 15 January 2018 Accepted: 7 May 2018

Published online: 16 May 2018

\section{References}

1. Gleiser RM, Gorla DE, Schelotto G. Population dynamics of Aedes albifasciatus (Diptera: Culicidae) south of Mar Chiquita Lake. Central Argentina. J Med Entomol. 2000;37:21-6.

2. Mitchell CJ, Monath TP, Sabattini MS, Daffner JF, Cropp CB, Calisher CH, et al. Arbovirus isolations from mosquitoes collected during and after the 1982-1983 epizootic of Western equine encephalitis in Argentina. Am J Trop Med Hyg. 1987;36:107-13.

3. Díaz LA, Llinás G, Vázquez A, Tenorio A, Contigiani MS. Silent circulation of St. Louis encephalitis virus prior to an encephalitis outbreak in Cordoba, Argentina (2005). PLoS Negl Trop Dis. 2012;6:e1489.

4. Tauro LB, Rivarola ME, Lucca E, Mariño B, Mazzini R, Cardoso JF, et al. First isolation of Bunyamwera virus (Bunyaviridae family) from horses with neurological disease and an abortion in Argentina. Vet J. 2015;206:111-4.

5. Vezzani D, Eiras DF, Wisnivesky C. Dirofilariasis in Argentina: Historical review and first report of Dirofilaria immitis in a natural mosquito population. Vet Parasitol. 2006;136:259-73.

6. Lourenço-de-Oliveira R. Alguns aspectos da ecologia dos mosquitos (Diptera: Culicidae) de uma area de planicie (Granja Calabria), em Jacarepegua, Rio de Janeiro. I. Frequencia comparativa das especies em diferentes ambientes e metodos de colecta. Mem Inst Oswaldo Cruz. 1984;79:479-90

7. Bachmann AO, Bejarano AO. Dispersión de mosquitos en la Patagonia (Dipt. Culicidae-Culicinae). Neotropica. 1960;6:1960.

8. Mitchell CJ, Darsie RF. Mosquitoes of Argentina Part II, geographic distribution and bibliography (Diptera, Culicidae). Mosq Syst. 1985;17:279-360.

9. Rossi GC, Lestani EA, Martín J. Nuevos registros y distribución de mosquitos de la Argentina (Diptera: Culicidae). Rev Soc Entomol Argent. 2006;65:51-6.

10. Duret JP. Datos sobre Culicidos de la región Cuyana (Diptera-Culicidae). Rev Sanid Milit Argent. 1954:8:412-3.

11. Bachmann $\mathrm{AO}, \mathrm{Casal} \mathrm{OH}$. Mosquitos argentinos que se crían en aguas salobres y saladas. Rev Soc Entomol Argent. 1962;25:21-7.

12. Garzón MJ, Jensen O, Schweigmann N. Environmental factors related to the abundance and activity of Ochlerotatus albifasciatus (Diptera: Culicidae) in an agricultural landscape of steppe arid climate. J Med Entomol. 2014;51: $733-41$.

13. De Souza GB, Jiménez A, Blanco A, Gardenal CN. Gene flow in Aedes albifasciatus (Diptera: Culiciade) from Central Argentina. J Med Entomol. 1996:33:894-900.

14. De Souza GB, de Dutari P, Gardenal CN. Genetic structure of Aedes albifasciatus (Diptera: Culicidae) populations in Central Argentina determined by random amplified polymorphic DNA- polymerase chain reaction markers. J Med Entomol. 1999:36:400-4.

15. Garzón MJ, Schweigmann N. Thermal response in pre-imaginal biology of Ochlerotatus albifasciatus from two different climatic regions. Med Vet Entomol. 2015;29:380-6.

16. Bradshaw WE, Fujiyama S, Holzapfel CM. Adaptation to the thermal climate of North America by the pitcher-plant mosquito, Wyeomyia smithii. Ecology. 2000;81:1262-72.

17. Stacey DA, Fellowes MDE. Temperature and the development rates of thrips: evidence for a constraint on local adaptation. Eur J Entomol. 2002; 127:399-404.

18. Takahashi KH. Genetic architecture of the development buffering machinery for wing shape in fruit flies. In: Lestrel P, editor. Biological shape analysis. Tokyo: World Scientific Publishing Co. Pte. Ltd.; 2013. p. 21-9. 
19. Christophers SR. Aëdes aegypti (L.) the yellow fever mosquito: its life history, bionomics and structure. Cambridge: Cambridge University Press; 1960.

20. Bomphrey RJ, Nakata T, Phillips N, Walker SM. Smart wing rotation and trailing-edge vortices enable high frequency mosquito flight. Nature. 2017 544:92-5.

21. Virginio F, Vidal PO, Suesdek L. Wing sexual dimorphism of pathogen-vector culicids. Parasit Vectors. 2015;8:159.

22. Whitman DW, Agrawal AA. What is phenotypic plasticity and why is it important? In: Whitman DW, Ananthakrishnan TN, editors. Phenotypic plasticity of insects. Enfield, NH: CRC Press; 2009. p. 1-63.

23. Dujardin J, Slice DE. Contributions of morphometrics to medical entomology. In: Tibayrenc M, editor. Encyclopedia of infectious diseases: modern methodologies. Hoboken, NJ: John Wiley \& Sons Inc.; 2007. p. 433-46.

24. Dvorak V, Aytekin M, Alten B, Skarupova S, Votypka J, Volf P. A comparison of the intraspecific variability of Phlebotomus sergenti Parrot, 1917 (Diptera: Psychodidae). J Vector Ecol. 2006:31:229-38.

25. Ancca J, Pinto J, Vega S, Cáceres AG, Náquira C. Características morfométricas, genéticas, alimenticias y vectoriales de Panstrongylus herreri procedentes de Jaén (Cajamarca) y Cajaruro (Amazonas), Perú. Rev Peru Med Exp en Salud Pública. 2008;25:17-25.

26. Armbruster P, Bradshaw WE, Ruegg K, Holzapfel CM. Geographic variation and the evolution of reproductive allocation in the pitcher-plant mosquito, Wyeomyia smithii. Evolution. 2001;55:439-44.

27. Chen B, Kang L. Variation in cold hardiness of Liriomyza huidobrensis (Diptera: Agromyzidae) along latitudinal gradients. Environ Entomol. 2004; 33:155-64.

28. Khatchikian CE, Dennehy JJ, Vitek CJ, Livdahl T. Climate and geographic trends in hatch delay of the tree hole mosquito, Aedes triseriatus Say (Diptera: Culicidae). J Vector Ecol. 2009;34:119-28.

29. Morais SA, Moratore C, Suesdek L, Marrelli MT. Genetic-morphometric variation in Culex quinquefasciatus from Brazil and La Plata. Argentina. Mem Inst Oswaldo Cruz. 2010;105:672-6.

30. De la Riva J, Le Pont F, Ali V, Matias A, Mollinedo S, Dujardin JP. Wing geometry as a tool for studying the Lutzomyia longipalpis (Diptera: Psychodidae) complex. Mem Inst Oswaldo Cruz. 2001;96:1089-94.

31. Gafur A, Ajizah A. The use of female wing measurements for discrimination of Aedes aegypti (L.) (Diptera: Culicidae) populations from South Kalimantan. Hayati J Biosci. 2008;15:8-12.

32. Kuclu O, Aldemir A, Demirci B. Altitudinal variation in the morphometric characteristics of Aedes vexans Meigen from northeastern Turkey. J Vector Ecol. 2011;36:30-41.

33. Jirakanjanakit N, Leemingsawat S, Thongrungkiat S, Apiwathnasorn C, Singhaniyom S, Bellec $\mathrm{C}$, et al. Influence of larval density or food variation on the geometry of the wing of Aedes (Stegomyia) aegypti. Trop Med Int Heal. 2007:12:1354-60.

34. Aytekin S, Aytekin M, Alten B. Effect of different larval rearing temperatures on the productivity ( $\mathrm{R} \circ$ ) and morphology of the malaria vector Anopheles superpictus Grassi (Diptera: Culicidae) using geometric morphometrics. J Vector Ecol. 2009;34:32-42.

35. Stephens ACR, Juliano SA. Wing shape as an indicator of larval rearing conditions for Aedes albopictus and Aedes aegypti (Diptera: Culicidae). J Med Entomol. 2012;49:927-38.

36. Peel MC, Finlayson BL, Mc Mahon TA. Updated world map of the KoppenGeiger climate classification. HESSD Earth Syst Sci Discuss. 2007:4:439-73.

37. Ñancucheo A, Mundet C, Iñurrita G, Winograd M. Desarrollo agropecuario en el Valle de Sarmiento - Chubut. Concurso Argentino Rural. 2008;1:1-21.

38. Paruelo JM, Beltran A, Jobbagy E, Sala OE, Golluscio RA. The climate of Patagonia: General patterns and controls on biotic processes. Ecologia Austral. 1998;8(2):85-101.

39. Ellis RA, Brust RA. Sibling species delimitation in the Aedes communis (Degeer) aggregate (Diptera: Culicidae). Can J Zool. 1973;51:915-59.

40. Gerberg EJ. Manual for mosquito rearing and experimental techniques. Mount Laurel, NJ: American Mosquito Control Association; 1970.

41. Rohlf FJ. tpsDIG2. 2017. http://life.bio.sunysb.edu/morph/morphmet/ tpsdig2w32.exe

42. Bookstein FL. Morphometric tools for landmark data. New York: Cambridge University Press; 1991.

43. Klingenberg CP. MorphoJ: An integrated software package for geometric morphometrics. Mol Ecol Resour. 2011;11:353-7.

44. Chatterjee S, Hadi AS, Price B. Regression analysis by example. 3rd ed Hoboken, NJ: John Wiley \& Sons Inc.; 2000.
45. Zar JH. Biostatistical analysis. New Jersey: Prentice-Hall; 1996.

46. Rohlf FJ. Relative warps analysis and an example of its application to mosquito wings. In: Marcus LF, Bello E, Garcia-Valdecasas A, editors. Contributions to morphometrics. 8th ed. Madrid: Monografías del Museo Nacional de Ciencias Naturales; 1993. p. 131-59.

47. Zelditch ML, Swiderski DL, Sheets HD, Fink WL. Geometric morphometrics for biologists: A primer. 1st ed. London: Elsevier Inc.; 2004.

48. Elewa AMT. Morphometrics for nonmorphometricians (lecture notes in earth sciences). 1st ed. Berlin: Springer; 2010.

49. Louise C, Vidal PO, Suesdek L. Microevolution of Aedes aegypti. PLoS One. 2015;10:1-16.

50. Bennett KE, Olson KE, Muñoz ML, Fernandez-Salas I, Farfan-Ale JA, Higgs S, et al. Variation in vector competence for dengue 2 virus among 24 collections of Aedes aegypti from Mexico and the United States. Am J Trop Med Hyg. 2002;67:85-92.

51. Goddard LB, Roth AE, Reisen WK, Scott TW. Vector competence of California mosquitoes for West Nile virus. Emerg Infect Dis. 2002:8:1385-91

52. Lyimo EO, Takken W, Koella JC. Effect of rearing temperature and larval density on larval survival, age at pupation and adult size of Anopheles gambiae. Entomol Exp Appl. 1992;63:265-71.

53. Loetti $V$, Schweigmann N, Burroni N. Development rates, larval survivorship and wing length of Culex pipiens (Diptera: Culicidae) at constant temperatures. J Nat Hist. 2011;45:2207-17.

54. Rueda LM, Patel KJ, Axtell RC, Stinner RE. Temperature-dependent development and survival rates of Culex quinquefasciatus and Aedes aegypti (Diptera: Culicidae). J Med Entomol. 1990;27:892-8.

55. Morales Vargas RE, Ya-umphan P, Phumala-Morales N, Komalamisra N, Dujardin JP. Climate associated size and shape changes in Aedes aegypti (Diptera: Culicidae) populations from Thailand. Infect Genet Evol. 2010;10:580-5.

56. Williams DD, Felmate BW. Aquatic insects. Wallingford: CAB International; 1992

57. Clements AN. Growth and development. In: The biology of mosquitoes. London: Chapman \& Hall; 1992.

58. Teder T, Tammaru T. Sexual size dimorphism within species increases with body size in insects. Oikos. 2005;108:321-34.

59. Vinogradova EB. Culex pipiens pipiens mosquitoes: taxonomy, distribution, ecology, physiology, genetics, applied importance and control. Pensoft: Sofia-Moscow; 2000.

60. Ruangsittichai J, Apiwathnasorn C, Dujardin JP. Interspecific and sexual shape variation in the filariasis vectors Mansonia dives and Ma. bonneae. Infect Genet Evol. 2011:11:2089-94.

61. Vidal PO, Carvalho E, Suesdek L. Temporal variation of wing geometry in Aedes albopictus. Mem Inst Oswaldo Cruz. 2012;107:1030-4

62. Horsfall WR, Anderson JF. Thermal stress and anomalous development of mosquitoes (Diptera: Culicidae). II. Effect of alternating temperatures on dimorphism of adults of Aedes stimulans. J Exp Zool. 1964;156:61-89.

63. Blackburn TM, Gaston KJ, Loder N. Geographic gradients in body size: A clarification of Bergmann's rule. Divers Distrib. 1999;5:165-74.

64. Bergmann C. Ueberdie Verhältnisse der Wärmeökonomie der Thierezuihrer Grösse. Gottinger Stud. 1847;3:595-708

65. Mousseau TA. Ectotherms follow the converse to Bergmann's rule. Evolution. 1997;51:630-2

66. Angilletta MJ, Niewiarowski PH, Dunham AE, Leache AD, Porter WP. Bergmann's clines in ectotherms: Illustrating a life-history perspective with sceloporine lizards. Am Nat. 2004;164:E168-83.

67. Shelomi M. Where are we now? Bergmann's rule sensu lato in insects. Am Nat. 2012;180:511-9.

68. Blanckenhorn WU, Demont M. Bergmann and converse Bergmann latitudinal clines in arthropods: two ends of a continuum? Integr Comp Biol. 2004:44:413-24

69. Henry A, Thongsripong P, Fonseca-Gonzalez I, Jaramillo-Ocampo N, Dujardin JP. Wing shape of dengue vectors from around the world. Infect Genet Evol. 2010;10:207-14.

70. Fischer S, Marinone MC, Schweigmann N. Ochlerotatus albifasciatus in rain pools of Buenos Aires: Seasonal dynamics and relation to environmental variables. Mem Inst Oswaldo Cruz. 2002:97:767-73.

71. Ludueña Almeida FF, Gorla DE. The biology of Aedes (Ochlerotatus) albifasciatus Macquart, 1838 (Diptera: Culicidae) in central Argentina. Mem Inst Oswaldo Cruz. 1995;90:463-8. 
72. Alves VM, Moura MO, de Carvalho CJB. Wing shape is influenced by environmental variability in Polietina orbitalis (Stein) (Diptera: Muscidae). Rev Bras Entomol. 2016;60:150-6.

73. Agrawal AA. Phenotypic plasticity in the interactions and evolution of species. Science. 2001;294:321-6.

74. Demirci B, Lee Y, Lanzaro GC, Alten B. Altitudinal genetic and morphometric variation among populations of Culex theileri Theobald (Diptera: Culicidae) from northeastern Turkey. J Vector Ecol. 2012;37:197-209.

Ready to submit your research? Choose BMC and benefit from:

- fast, convenient online submission

- thorough peer review by experienced researchers in your field

- rapid publication on acceptance

- support for research data, including large and complex data types

- gold Open Access which fosters wider collaboration and increased citations

- maximum visibility for your research: over $100 \mathrm{M}$ website views per year 